\title{
HEXAFLUOROSILICATES WITH ANTIBACTERIAL ACTIVE GUANIDINE CONTAINING CATIONS
}

\author{
V.O.Gelmboldt, V.Yu.Anisimov, O.V.Prodan \\ Odessa National Medical University \\ Key words: hexafluorosilicates; antibacterial active cations; structure; thermochemical \\ transformations; hydrolysis
}

\begin{abstract}
The present research has studied the spectral data, thermochemical transformations and hydrolysis of hexafluorosilicates with guanidine containing cations $\left(\mathrm{C}_{22} \mathrm{H}_{32} \mathrm{Cl}_{2} \mathrm{~N}_{10}\right) \mathrm{SiF}_{6}(\mathrm{I})$ and $\left(\mathrm{C}_{21} \mathrm{H}_{45} \mathrm{~N}_{9}\right)\left(\mathrm{SiF}_{6}\right)_{1.5}$ (II) for their potential use as caries-preventive and antibacterial agents. Hexafluorosilicates of the composition I and II were separated as crystalline products of interaction of hexafluorosilicic acid with the methanol solutions of chlorhexidine hydrochloride and polyhexamethylene guanidine hydrochloride. The compounds isolated have been characterized by IR, NMR ${ }^{19} \mathrm{~F}$, mass-spectrometry, thermogravimetric analysis, potentiometry. According to IR spectroscopy data, "onium" hexafluorosilicates I and II have ionic structures. The vibrations of the groups $v(\mathrm{NH}), v\left(\mathrm{~N}^{+} \mathrm{H}_{2}\right)$ in salts I and II appear as strong absorption bands at 3360-3180 $\mathrm{cm}^{-1} ; \delta\left(\mathrm{N}^{+} \mathrm{H}_{2}\right)$ vibrations appear at 1634 and $1637 \mathrm{~cm}^{-1}$. The strong $v(\mathrm{SiF})$ and $\delta\left(\mathrm{SiF}_{2}\right)$ stretches of $\mathrm{SiF}_{6}{ }^{2-}$ anions are observed in their characteristic regions (at 744, 734 and $482 \mathrm{~cm}^{-1}$, respectively). The singlet character of $v(\mathrm{SiF})$ and $\delta\left(\mathrm{SiF}_{2}\right)$ vibrations indicates the absence of noticeable distortion of symmetry of $\mathrm{SiF}_{6}{ }^{2-}$ anion with regard to $\mathrm{O}_{h}$. The NMR ${ }^{19} \mathrm{~F}$ spectra of compounds I and II (in DMSO-d 6 solutions) have one resonance at $-136,70,-135,09 \mathrm{ppm}\left(\mathrm{SiF}_{6}{ }^{2-}\right)$; additional resonance at $-123,14 \mathrm{ppm}$, in the case of II it can be related to the octahedral complex anion $\left[\mathrm{SiF}_{5}(\mathrm{ДMCO})\right]$. The results of thermogravimetric analysis are consistent with a multi-stage thermolysis scheme for hexafluorosilicates I and II. The temperatures of thermolysis beginning of complexes I and II are 270 and $100^{\circ} \mathrm{C}$, respectively. The compounds I and II studied are characterized by the predicted tendency to hydrolysis in dilute aqueous solutions with formation of orthosilicic acid and fluoride ions, and it allows considering these salts as potential anticaries agents. The study of the biological activity of these compounds is the subject of further investigations.
\end{abstract}

In recent years, several research groups consisting of experts from Japan, the United States [10-13] and Armenia $[1,8]$ demonstrated the possible use of ammonium and amino acids hexafluorosilicates as caries-preventive and hyposensitive agents in dental practice. These results $[1,8,10-13]$ allow to consider the "onium" hexafluorosilicates as a promising new class of drugs possessing a number of advantages compared to the conventional agents of fluoride caries therapy such as sodium and potassium fluorides, silver diamine fluoride, tin fluoride and sodium monofluorophosphate. The active components of treatment and prevention of dental caries are also antibacterial agents, including high efficient guanidine derivatives (chlorhexidine, polyhexamethylene guanidine hydrochloride, etc.) $[9,13]$. In principle, introducing guanidine containing cations possessing the antibacterial action into the composition of hexafluorosilicate allows to obtain compounds for which the caries-preventive effect of the anion is intensified by the bactericidal action of the cation. The aim of this work is the synthesis, the study of the structure and properties of chlorhexidine $(\mathrm{CH})$ and polyhexamethylene guanidine (PHMG) hexafluorosilicates the first representatives of fluoride-containing salts combined with cations exhibiting the antibacterial activity.

\section{Materials and Methods}

The synthesis of hexafluorosilicates was performed by the ion exchange reaction between methanol solu- tions of the corresponding hydrochloride (HC) (Hangzhou dayangchem Co., Ltd, China) and the solution of $45 \%$ fluorosilicic acid (the molar ratio of $\mathrm{HC}: \mathrm{H}_{2} \mathrm{SiF}_{6}$ $=1: 3$ ). The reaction mixtures were kept at room temperature to evaporate the solvents and obtain colourless crystalline products. The nitrogen content was determined according to Kjeldahl [5] and the silicon content by the photocolorimetric method [6].

The IR-absorption spectra were recorded on a Spectrum BX II FT-IR System spectrophotometer (PerkinElmer) (the range was $4000-350 \mathrm{~cm}^{-1}$, the samples were in the form of tablets with $\mathrm{KBr}$ ). The EI mass spectra were recorded on a MX-1321 spectrophotometer (a direct introduction of a sample into the source, the energy of ionizing electrons was $70 \mathrm{eV}$ ), FAB mass spectra on a VG 7070 spectrometer (VG Analytical) (desorption of ions from the surface of the liquid phase was performed by a beam of argon atoms with the energy of $8 \mathrm{keV}, m$-nitrobenzyl alcohol was used as a matrix). The ${ }^{19} \mathrm{~F}$ NMR spectra were recorded on a Varian VXR-300 spectrometer $\left(282 \mathrm{MHz}\right.$, the solvent was DMSO- $\mathrm{d}_{6}$ with $\mathrm{CFCl}_{3}$ as a standard, the temperature was $27^{\circ} \mathrm{C}$ ). Thermogravimetric analysis was performed on a Q-1500 D derivatograph of F. Paulik - J. Paulik - L. Erdey's system (platinum crucibles, samples of 80-100 $\mathrm{mg}$, the temperature range was $20-1000^{\circ} \mathrm{C}$, the sample weight heating rate was $10 \% \mathrm{~min}, \mathrm{Al}_{2} \mathrm{O}_{3}$ as standard). 
Table 1 areas of 3400-3180 and $1640-1630 \mathrm{~cm}^{-1}$, respectively;

Wave numbers $\left(\mathrm{cm}^{-1}\right)$ of the absorption band maxima in IR spectra of chlorhexidine (I) and polyhexamethylene guanidine (II) hexafluorosilicates

\begin{tabular}{|c|c|c|}
\hline 1 & II & Assignment \\
\hline 3401 s.br. & 3354 s.br. & \multirow{3}{*}{$\mathrm{v}(\mathrm{NH}), \mathrm{v}\left(\mathrm{N}^{+} \mathrm{H}_{2}\right.$} \\
\hline & 3251 sh. & \\
\hline 3207 s.br. & 3187 sh. & \\
\hline 2926 s. & 2936 s. & $\mathrm{v}_{\mathrm{as}}\left(\mathrm{CH}_{2}\right)$ \\
\hline 2862 sh. & $2861 \mathrm{~m}$. & $\mathrm{v}_{\mathrm{s}}\left(\mathrm{CH}_{2}\right)$ \\
\hline $1690 \mathrm{~s}$. & $1656 \mathrm{~s}$. & $\mathrm{v}(\mathrm{C}=\mathrm{N})$ \\
\hline $1634 \mathrm{~m}$. & 1637 sh. & $\delta\left(\mathrm{N}^{+} \mathrm{H}_{2}\right)$ \\
\hline $1550 \mathrm{~m}$. & & $\mathrm{v}(\mathrm{CC})_{\text {arom }}$ \\
\hline $1493 \mathrm{~m}$. & & $\mathrm{v}(\mathrm{CC})_{\text {arom }}$ \\
\hline $1462 \mathrm{~m}$. & $1473 \mathrm{~m}$. & $\delta_{s}\left(\mathrm{CH}_{2}\right)$ \\
\hline 1384 m.br. & & $\delta(\mathrm{NH})+v(\mathrm{CN})$ \\
\hline 1249 m. & & $\mathrm{v}\left(\mathrm{C}_{\text {arom }} \mathrm{N}\right)$ \\
\hline $1095 \mathrm{~s}$. & & $\mathrm{v}\left(\mathrm{C}_{\text {arom }} \mathrm{Cl}\right)$ \\
\hline $1017 \mathrm{~m}$. & 1026 w. & $\mathrm{v}\left(\mathrm{C}_{\text {aliph }} \mathrm{N}\right)$ \\
\hline 744 s. & $734 \mathrm{~s}$. & $\mathrm{v}(\mathrm{SiF})$ \\
\hline $482 \mathrm{~m}$. & $482 \mathrm{~m}$. & $\delta\left(\mathrm{SiF}_{2}\right)$ \\
\hline
\end{tabular}

Note: $\mathrm{w}=$ weak, $\mathrm{m}=$ medium $\mathrm{s}=$ strong, $\mathrm{v}=$ very, $\mathrm{sh}=$ shoulder, $\mathrm{br}=\mathrm{broad}$

The $\mathrm{pH}$ values of aqueous solutions of hexafluorosilicates were determined using an EV-74 universal ionomer.

\section{Results and Discussion}

The composition of the compounds isolated has been determined by the elementary analysis data.

Found, \%: $\mathrm{N}-21.41 ; \mathrm{Si}-4.50$.

For $\left(\mathrm{C}_{22} \mathrm{H}_{32} \mathrm{Cl}_{2} \mathrm{~N}_{10}\right) \mathrm{SiF}_{6}$ (I) calculated,\%: $\mathrm{N}-21.56$; $\mathrm{Si}-4.32$.

Found, \%: $\mathrm{N}-19.89 ; \mathrm{Si}-4.22$.

For $\left(\mathrm{C}_{21} \mathrm{H}_{45} \mathrm{~N}_{9}\right)\left(\mathrm{SiF}_{6}\right)_{1.5}$ (II) calculated, \%: $\mathrm{N}-19.70$; $\mathrm{Si}-4.39$.

The mass spectrum EI I: $\left[\mathrm{ClC}_{6} \mathrm{H}_{4} \mathrm{CH}_{2} \mathrm{~N}_{2}\right]^{+}(m / z=153$, $I=8 \%),\left[\mathrm{ClC}_{6} \mathrm{H}_{4} \mathrm{NH}_{2}\right]^{+}(m / z=127, I=100 \%),\left[\mathrm{SiF}_{3}\right]^{+}$ $(\mathrm{m} / \mathrm{z}=85, I=20 \%),\left[\mathrm{C}_{5} \mathrm{H}_{12}\right]^{+}(\mathrm{m} / \mathrm{z}=72, I=9 \%),\left[\mathrm{C}_{3} \mathrm{H}_{6}\right]^{+}$ $(m / z=42, I=6 \%)$.

The mass spectrum FAB I: $\left[\mathrm{M}_{\mathrm{HG}}\right]^{+}(\mathrm{m} / z=505, I=2 \%)$.

The mass spectrum EI II: $\left[\mathrm{NH}(\mathrm{C}=\mathrm{NH}) \mathrm{NH}\left(\mathrm{CH}_{2}\right)_{6}+\mathrm{H}\right]^{+}$ $(\mathrm{m} / z=142, I=2 \%),\left[\mathrm{SiF}_{3}\right]^{+}(\mathrm{m} / z=85, I=100 \%),\left[\mathrm{C}_{5} \mathrm{H}_{12}\right]^{+}$ $(\mathrm{m} / z=72, I=5 \%),\left[\mathrm{C}_{5} \mathrm{H}_{11}\right]^{+}(\mathrm{m} / z=71, I=7 \%),\left[\mathrm{C}_{4} \mathrm{H}_{7}\right]^{+}$ $(\mathrm{m} / z=55, I=7 \%),\left[\mathrm{C}_{3} \mathrm{H}_{6}\right]^{+}(\mathrm{m} / z=42, I=15 \%)$.

Characteristics of IR spectra of compounds I and II are presented in Table 1, with vibration rating carried out using the data in [7]. Stretching $v(\mathrm{NH}), v\left(\mathrm{~N}^{+} \mathrm{H}_{2}\right)$ and deformation $\delta\left(\mathrm{N}^{+} \mathrm{H}_{2}\right)$ vibrations of cations occur in the

Table 2

The $\mathrm{pH}$ values of aqueous solutions of salts I and II

\begin{tabular}{|c|c|c|}
\hline Compound & $\begin{array}{c}\mathrm{pH} \text { of } 1 \times 10^{-3} \mathrm{M} \\
\text { solutions }\end{array}$ & $\begin{array}{c}\mathrm{pH} \text { of } 1 \times 10^{-4} \mathrm{M} \\
\text { solutions }\end{array}$ \\
\hline I & 3.14 & 5.16 \\
\hline II & 3.21 & 5.14 \\
\hline
\end{tabular}

a diffused nature of $v(\mathrm{NH})$ and $v\left(\mathrm{~N}^{+} \mathrm{H}_{2}\right)$ maxima may indicate the participation of groups $=\mathrm{NH}$ and $-\mathrm{N}^{+} \mathrm{H}_{2}$ in $\mathrm{H}$-bonds of $\mathrm{NH} \cdots \mathrm{F}$ with fluorine atoms of hexafluorosilicates anions. A singlet type of vibration bands $v(\mathrm{SiF})$ and $\delta\left(\mathrm{SiF}_{2}\right)$ for anions $\mathrm{SiF}_{6}{ }^{2-}$ (identified in characteristic spectral regions I and II at 744, 734 and $482 \mathrm{~cm}^{-1}$, respectively) reflect apparently proximity of the anions structure to the idealized $O_{\mathrm{h}}$-symmetry.

Low solubility of I and II in chloroform did not allow to carry out the registration of ${ }^{19} \mathrm{~F}$ NMR spectra of salts in the medium of the given solvent. In the ${ }^{19} \mathrm{~F}$ NMR I and II spectra in the solution of dimethyl sulfoxide (DMSO) singlet signals with chemical shifts $\delta_{\mathrm{F}}=$ -136.70-135.09 ppm, respectively, correspond to $\mathrm{SiF}_{6}{ }^{2-}$ anion. Along with $\mathrm{SiF}_{6}{ }^{2-}$ anion signal, the signal with $\delta_{\mathrm{F}}=-123.14 \mathrm{ppm}$ referred to equatorial fluorine atoms of octahedral anion $\left[\mathrm{SiF}_{5}(\mathrm{DMSO})\right]^{-}-$the product of $\mathrm{SiF}_{6}{ }^{2-}$ anion solvolysis is also recorded in ${ }^{19} \mathrm{~F}$ NMR II spectrum.

Judging by the thermogravimetric analysis data the thermal decomposition of compound $\mathbf{I}$ is accompanied by elimination of 2 moles of HF in the gas phase (the endothermic effect on the curves of DTG and DTA at $t_{0}$ $=270^{\circ} \mathrm{C}, t_{\max }=300^{\circ} \mathrm{C} ; \Delta \mathrm{m}_{\text {eksp }}=8.3 \%, \Delta \mathrm{m}_{\text {calc }}=6.2 \%$ ), $1 \mathrm{~mole}^{\circ} \mathrm{SiF}_{4}$ (the endothermic effect at $t_{0}=350^{\circ} \mathrm{C}, t_{\max }$ $=400^{\circ} \mathrm{C} ; \Delta \mathrm{m}_{\text {eksp }}=33.3 \%, \Delta \mathrm{m}_{\text {calc }}=22.2 \%$ ), degradation products of $\mathrm{CH}$ and their oxidation (endothermic and exothermic effects at $t_{0}=440^{\circ} \mathrm{C}, t_{\text {max }}=480^{\circ} \mathrm{C}$ and $t_{0}=$ $690^{\circ} \mathrm{C}, t_{\text {max }}=750^{\circ} \mathrm{C}$, respectively). The evident excess of the value of the weight loss I experimentally determined compared to the calculated value in the case of $\mathrm{SiF}_{4}$ removal effect may be due to the superposition of $\mathrm{CH}$ expansion effect. The total weight loss of the sample $\mathbf{I}$ is $93.3 \%$.

Complex II is differentiated by lower thermal resistance than complex I. Thermolysis II begins at $100^{\circ} \mathrm{C}$, on DTA and DTG curves a series of endothermic effects is fixed at $t_{\max }=120,170,200,270,340,480^{\circ} \mathrm{C}$ and exothermic effect at $t_{\max }=660^{\circ} \mathrm{C}$. The total weight loss of sample II is $98.3 \%$. The proximity of the thermal stability II and PHMG HC studied earlier by the pyrolysis mass spectrometry method should be noted [4].

Attempt to determine the extent of hydrolysis of compounds I and II at $1 \times 10^{-4} \mathrm{M}$ of the aqueous solution using the spectrophotometric method $[3,6]$ based on the ability of orthosilicic acid - the product hydrolysis - to form a yellow-coloured silico-molybdic complex with ions $\mathrm{MoO}_{4}{ }^{2-}$ failed due to intense opalescence of solutions. But the fact of hydrolysis of $\mathrm{SiF}_{6}{ }^{2-}$ ion according to the scheme (1) is confirmed by the expected development of a yellow coloration of the solution after addition of $\left(\mathrm{NH}_{4}\right)_{2} \mathrm{MoO}_{4}$ :

$$
\mathrm{SiF}_{6}{ }^{2-}+4 \mathrm{H}_{2} \mathrm{O} \rightleftarrows \mathrm{Si}(\mathrm{OH})_{4}+6 \mathrm{~F}^{-}+4 \mathrm{H}^{+} .
$$

The results of $\mathrm{pH}$ determination of diluted aqueous solutions of salts (Table 2) indicate the hydrolytic instability of compounds I and II: pH values are in the "acidic" region and close to the corresponding values for the aqueous solutions of pyridinium hexafluorosilicates [2]. 
CONCLUSIONS

The synthesis has been performed, the spectral characteristics and physico-chemical properties have been studied, and the conclusion has been made about the probable struc- ture of hexafluorosilicates of chlorhexidine and polyhexamethylene guanidine as potential caries-preventive and antibacterial agents. Evaluation of the biological activity of the compounds obtained will be the subject of our further research.

\section{REFERENCES}

1. Андриасян Л.Г., Бадалян Г.Р., Брсикян Н.А. и др. // Вестник стоматол. и челюстно-лицевой хирургии. 2012. - T. 9, №1. - C. 26-30.

2. Анисимов В.Ю., Гельмбольдт В.О., Кузьмин В.Е. и др. // Одеський мед. журн. - 2013. - №1. - С. 6-10.

3. Анисимов В.Ю., Гельмбольдт В.О., Продан О.В. // Одеський мед. журн. - 2013. - №2. - С. 20-23.

4. Бойко В.В., Бортниикий В.И., Дмитриева Т.В. и др. // Полімерний журн. - 2008. - Т. 30, №3. - С. 251-255.

5. Климова В.А. Основные микрометоды анализа органических соединений. - М.: Химия, 1975. - 224 c.

6. Мышляева Л.В., Красношеков В.В. Аналитическая химия кремния. - М.: Наука, 1972. - 212 c.

7. Преч Э., Бюльманн Ф., Аффольтер К. Определение строения органических соединений. Таблицы спектральнылх данных. - М.: Мир; Бином. Лаборатория знаний, 2006. - 438 c.

8. Andriasyn L.H., Badalyan G.R., Brsikyan N.A. et al. // The New Armenian Med. J. - 2012. - Vol. 6, №4. P. 52-55.

9. Eley B.M. // Brit. Dent. J. - 1999. - Vol. 186, №6. - P. 286-296.

10. Hosoya Y., Otani H., Tadokore K. et al. // J. Oral Sci. - 2013. - Vol. 55, №2. - P. 115-121.

11. Hosoya Y., Tadokore K., Watanabe E. et al. // J. Oral Sci. - 2012. - Vol. 54, №3. - P. 267-272.

12. Ishikawa K., Kawasaki A., Suge T. et al. // Dent. Mater. - 2008. - Vol. 24, №2. - P. 192-198.

13. Kimura T., Shibata S., Suge T. et al. // Am. J. Dent. - 2012. - Vol. 25, №1. - P. 31-34.

\section{ГЕКСАФТОРОСИЛІКАТИ 3 ГУАНІДИНОВМІСНИМИ КАТІОНАМИ, ЩО ВИЯВЛЯЮТЬ АНТИБАКТЕРІАЛЬНУ АКТИВНІСТЬ \\ В.О.Гельмбольдт, В.Ю.Анісімов, О.В.Продан \\ Ключові слова: гексафторосилікати; бактерицидні катіони; будова; термохімічні перетворення; гідроліз}

З використанням реакцій іонного обміну між гідрохлоридами хлорогексидину (полігексаметиленгуанідину) і кремнефтороводневою кислотою в середовищі метанолу синтезовані гексафоторосилікати відповідних гуанідиновмісних катіонів $\left(\mathrm{C}_{22} \mathrm{H}_{32} \mathrm{Cl}_{2} \mathrm{~N}_{10}\right) \mathrm{SiF}_{6}(\mathrm{I}) \mathrm{ma}\left(\mathrm{C}_{21} \mathrm{H}_{45} \mathrm{~N}_{9}\right)\left(\mathrm{SiF}_{6}\right)_{1.5}(\mathrm{II})$, що становлять інтерес у якості потенційних карієспротекторних і бактерицидних агентів. Виділені сполуки складу I і II охарактеризовані методами I4-, ЯMP ${ }^{19} \mathrm{~F}-$, мас-спектроскопії, термогравіметричного аналізу, потенціометрії. Згідно з даними ІЧ-спектроскопії "онієві» гексафрторосилікати I i II мають іонну будову. Коливання v( $\mathrm{NH}), \mathrm{v}\left(\mathrm{N}^{+} \mathrm{H}_{2}\right)$ у спектрах I i II виявляються у вигляді інтенсивних смуг поглинання при 3360-3180 $\mathrm{cm}^{-1}$; коливання $\delta\left(\mathrm{N}^{+} \mathrm{H}_{2}\right)-$ при 1634 і 1637 см $^{-1}$. Інтенсивні смуги коливань v(SiF) i $\delta\left(\mathrm{SiF}_{2}\right)$ аніонів $\mathrm{SiF}_{6}{ }_{6}^{2-}$ спостеріааються в

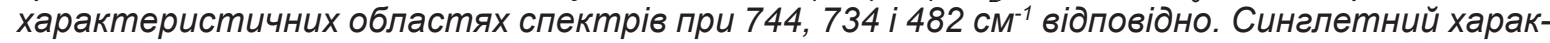
тер коливань v(SiF) i $\delta\left(\mathrm{SiF}_{2}\right)$ вказує на відсутність помітних відхилень геометрії аніонів $\mathrm{SiF}_{6}^{2-}$ відносно $\mathrm{O}_{h}$-симетрії. У спектрах ЯMP ${ }^{19} \mathrm{~F}$ розчинів солей I $\mathrm{i} / \mathrm{l}$ в ДМCO-d ${ }_{6}$ аніонам $\mathrm{SiF}_{6}{ }_{6}^{2-}$ відповідають резонансні сигнали з хімічними зсувами -136,70, -135,09 м.д.; додатковий резонансний сигнал при -123,14 м.д. у спектрі II може відноситися до октаедричного комплексного аніона $\left[\mathrm{SiF}_{5}(Д \mathrm{MCO})\right]^{-}$. Результати термогравіметричного аналізу узгоджуються з багатоступінчастою схемою термолізу I $\mathrm{i}$ II. Температури початку термолізу комплексів I i II складають 270 i $100^{\circ} \mathrm{C}$ відповідно. Сполуки I i II характеризуються очікуваною схильністю до гідролізу в розведених водних розчинах з утворенням ортокремнієвої кислоти і фтторид-іонів, що дозволяє розглядати зазначені солі в якості потенційних антикарієсних агентів. Вивчення біологічної активності отриманих сполук буде предметом наших подальщих досліджень.

ГЕКСАФТОРОСИЛИКАТЫ С ГУАНИДИНСОДЕРЖАЩИМИ КАТИОНАМИ, ПРОЯВЛЯЮЩИМИ АНТИБАКТЕРИАЛЬНУЮ АКТИВНОСТЬ

\section{В.О.Гельмбольдт, В.Ю.Анисимов, О.В.Продан}

Ключевые слова: гексафоторосиликаты; бактерицидные катионы; строение;

термохимические превращения; гидролиз

С использованием реакций ионного обмена между гидрохлоридами хлоргексидина (полигексаметиленгуанидина) и кремнефтороводородной кислотой в среде метанола синтезированы гексафрторосиликаты соответствующих гуанидинсодержащих катионов $\left(\mathrm{C}_{22} \mathrm{H}_{32} \mathrm{Cl}_{2} \mathrm{~N}_{10}\right) \mathrm{SiF}_{6}(\mathrm{I})$ u $\left(\mathrm{C}_{21} \mathrm{H}_{45} \mathrm{~N}_{9}\right)\left(\mathrm{SiF}_{6}\right)_{1.5}(\mathrm{II})$, представляющие интерес в качестве потенциальных кариеспротекторных и бактерицидных агентов. Выделенные соединения состава I и II охарактеризованы 
методами ИК-, ЯМР ${ }^{19} \mathrm{~F}$-, масс-спектроскопии, термогравиметрического анализа, потенциометрии. Согласно данным ИК-спектроскопии «ониевые» гексафторосиликаты I и II имеют ионное строение. Колебания $v(\mathrm{NH}), \mathrm{v}\left(\mathrm{N}^{+} \mathrm{H}_{2}\right)$ в спектрах I и II проявляются в виде интенсивных полос поглощения при 3360-3180 $\mathrm{cm}^{-1}$; колебания $\delta\left(\mathrm{N}^{+} \mathrm{H}_{2}\right)$ - при 1634 и $1637 \mathrm{~cm}^{-1}$. Интенсивные полосы колебаний v(SiF) и $\delta\left(\mathrm{SiF}_{2}\right)$ анионов $\mathrm{SiF}_{6}{ }^{2-}$ наблюдаются в характеристических обла-

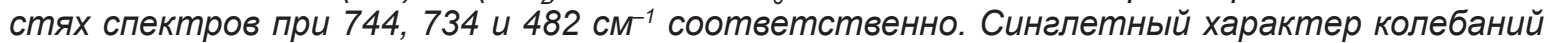
$v(\mathrm{SiF})$ и $\delta\left(\mathrm{SiF}_{2}\right)$ указывает на отсутствие заметных искажений геометрии анионов $\mathrm{SiF}_{6}^{2-}$ относительно $\mathrm{O}_{h}$-симметрии. В спектрах ЯMP ${ }^{19} \mathrm{~F}$ растворов солей I и II в ДМСО- $d_{6}$ анионам $\mathrm{SiF}_{6}{ }^{2-}$ соответствуют резонансные сигналы с химическими сдвигами -136, 70, -135,09 м.д.; дополнительный резонансный сигнал при -123,14 м.д. в спектре II может относиться к октаэдрическому комплексному аниону $\left[\mathrm{SiF}_{5}(\right.$ ДМС)]. Результаты термогравиметрического анализа согласуются с многоступенчатой схемой термолиза I и II. Температуры начала термолиза комплексов I и I/ составляют 270 и $100^{\circ} \mathrm{C}$ соответственно. Соединения I и II характеризуются ожидаемой склонностью к гидролизу в разбавленных водных растворах с образованием ортокремниевой кислоты и фтторид-ионов, что позволяет рассматривать указанные соли в качестве потенциальных антикариесных агентов. Изучение биологической активности полученных соединений будет предметом наших дальнейших исследований. 